\title{
PENGARUH PEMBELAJARAN KOOPERATIF MODEL THINK PAIR SHARE (TPS) DENGAN PENDEKATAN PROBLEM POSING MENGGUNAKAN DESAIN PEMBELAJARAN ASSURE TERHADAP PRESTASI BELAJAR SISWA PADA MATA PELAJARAN MEKANIKA TEKNIK KELAS X DPIB A SMKN 4 SUKOHARJO TAHUN AJARAN 2017/2018
}

\author{
Marlina Dwi Safitri ${ }^{1}$, Roemintoyo ${ }^{2}$, Rima Sri Agustin ${ }^{2}$ \\ Email: marlinadwisafitri@gmail.com
}

\begin{abstract}
ABSTRAK
Proses pembelajaran di sekolah saat ini lebih terfokus pada guru yang menyebabkan siswa kurang aktif dalam pembelajaran. Hal ini berdampak pada kurangnya pemahaman siswa terhadap materi yang diajarkan sehingga prestasi belajar menjadi rendah. Penelitian ini bertujuan untuk mengetahui pengaruh pembelajaran kooperatif Model Think Pair Share (TPS) dengan pendekatan Problem Posing menggunakan desain pembelajaran ASSURE terhadap prestasi belajar siswa. Penelitian ini merupakan penelitian tindakan kelas yang dilaksanakan di kelas X DPIB A SMK Negeri 4 Sukoharjo yang berjumlah 30 siswa. Penelitian ini dilaksanakan dalam dua siklus. Setiap siklus terdiri dari tahap perencanaan, pelaksanaan, observasi dan refleksi. Instrumen penelitian yang digunakan terdiri dari penilaian kognitif, psikomotor dan afektif. Uji validitas data pada penelitian ini menggunakan triangulasi data. Hasil penelitian menunjukkan bahwa penerapan model pembelajaran kooperatif Think Pair Share (TPS) dengan pendekatan Problem Posing menggunakan desain pembelajaran ASSURE dapat meningkatkan prestasi belajar siswa kelas X DPIB A SMKN 4 Sukoharjo. Pencapaian ketuntasan hasil belajar siswa menunjukkan persentase ketuntasan ranah kognitif awalnya $16,67 \%$ menjadi $46,67 \%$ pada siklus I dan $70 \%$ pada siklus II; ranah psikomotor awalnya $26,67 \%$ menjadi $46,67 \%$ pada siklus I dan $73,33 \%$ pada siklus II; ranah afektif awalnya $23,33 \%$ menjadi $43,33 \%$ pada siklus I dan $70 \%$ pada siklus II.
\end{abstract}

Kata kunci: Think Pair Share, Problem Posing, ASSURE, prestasi belajar siswa

\footnotetext{
${ }^{1}$ Mahasiswa Program Studi Pendidikan Teknik Bangunan FKIP UNS

${ }^{2}$ Dosen Pengajar Program Studi Pendidikan Teknik Bangunan FKIP UNS
} 


\title{
INFLUENCE OF COOPERATIVE LEARNING THINK PAIR SHARE (TPS) WITH PROBLEM POSING APPROACH USING ASSURE LEARNING DESIGN ON STUDENT LEARNING ACHIEVEMENTS OF THE ENGINEERING MECHANICS SUBJECT IN SMK NEGERI 4 SUKOHARJO LESSON YEAR 2017/2018
}

\author{
Marlina Dwi Safitri ${ }^{1}$, Roemintoyo ${ }^{2}$, Rima Sri Agustin ${ }^{2}$ \\ Email: marlinadwisafitri@gmail.com
}

\begin{abstract}
The learning process in schools is currently more focused on teachers which causes students to be less active in learning. This has an impact on the lack of student understanding of the material being taught so that learning achievement becomes low. This study aims to determine the effect of cooperative learning Think Pair Share (TPS) Model with Problem Posing approach using ASSURE learning design on student learning achievement. This research is a classroom action research conducted in class X DPIB A of SMK Negeri 4 Sukoharjo, amounting to 30 students. This research was conducted in two cycles. Each cycle consists of the stages of planning, implementation, observation and reflection. The research instrument used consisted of cognitive, psychomotor and affective assessments. The test validity of the data in this study using data triangulation. The results showed that the application of the Think Pair Share (TPS) cooperative learning model with the Problem Posing approach using the ASSURE learning design could improve the learning achievement of class X DPIB A students of SMK 4 Sukoharjo. Achievement of student learning outcomes showed the percentage of completeness of the cognitive domain initially $16.67 \%$ to $46.67 \%$ in the first cycle and $70 \%$ in the second cycle; the psychomotor domain was initially $26.67 \%$ to $46.67 \%$ in the first cycle and $73.33 \%$ in the second cycle; the affective domain was initially $23.33 \%$ to $43.33 \%$ in the first cycle and $70 \%$ in the second cycle.
\end{abstract}

Keywords: Think Pair Share, Problem Posing, ASSURE, student learning achievement

\footnotetext{
${ }^{1}$ Student of Building Engineering of Education FKIP UNS

${ }^{2}$ Lecturer of Building Engineering of Education FKIP UNS
} 


\section{PENDAHULUAN}

Pendidikan merupakan salah satu masalah yang sangat penting untuk mendapatkan perhatian dan penanganan yang sesuai dengan perkembangan jaman dan dunia pendidikan. Berbagai cara dan usaha yang digunakan untuk memajukan pendidikan dan mengatasi berbagai masalah yang timbul guna menunjang tujuan pendidikan. Tujuan Pendidikan Nasional sesuai dengan undangundang No. 20 tahun 2003 (Sisdiknas, 2012: 2) tentang pendidikan nasional menyatakan pendidikan nasional berfungsi mengembangkan kemampuan dan membentuk watak serta peradaban bangsa yang bermanfaat dalam rangka mencerdaskan kehidupan bangsa. Hal ini bertujuan untuk mengembangkan potensi siswa supaya menjadi manusia yang beriman kepada Tuhan Yang Maha Esa. Siswa diharapkan berakhlak mulia, berilmu, kreatif, mandiri dan menjadi warga Negara yang bertanggung jawab.

Sekolah Menengah Kejuruan (SMK) mempunyai tujuan menghasilkan lulusan yang terampil. Siswa diharapkan mampu mengikuti perkembangan jaman dan dunia pendidikan agar dapat memiliki daya saing yang tinggi sesuai bidang kemampuannya. Oleh karena itu, peneliti ingin menerapkan model pembelajaran yang menarik untuk meningkatkan kualitas belajar siswa.

Berdasarkan hasil observasi dan wawancara selama Magang Kependidikan 3 dan pelaksanaan penelitian di SMK Negeri 4 Sukoharjo, diperoleh hasil bahwa prestasi belajar siswa pada mata pelajaran Mekanika masih rendah. Data yang diperoleh dari hasil observasi adalah rata-rata nilai Ujian
Tengah Semester (UTS) siswa kelas X Desain Pemodelan dan Informasi Bangunan (DPIB) pada mata pelajaran Mekanika Teknik SMK Negeri 4 Sukoharjo Tahun Ajaran 2017/2018 semester I yaitu sebagai berikut:

Rata-rata nilai UTS Siswa Kelas X DPIB A yaitu 66, dari 30 siswa hanya 3 siswa yang memenuhi nilai KKM (Kriteria Ketuntasan Minimal) dan masih terdapat 27 siswa yang belum memenuhi KKM (Kriteria Ketuntasan Minimal), KKM yang ditetapkan adalah sebesar 76. Sehingga presentase siswa yang lulus hanya $10 \%$ dan masih terdapat $90 \%$ siswa yang mendapat nilai dibawah KKM.

Salah satu solusi yang dilakukan oleh guru untuk mengatasi masalah yang teridentifikasi di kelas X DPIB A SMKN 4 Sukoharjo adalah dipilih pembelajaran yang memberikan kesempatan bagi siswa untuk lebih aktif dalam pembelajaran Mekanika Teknik. Salah satu alternatif yang dapat ditempuh adalah dengan pendekatan Problem Posing tipe Presolution Posing. Pendekatan Problem Posing merupakan suatu pendekatan yang mewajibkan siswanya untuk mengajukan soal atau pertanyaan. Dalam pendekatan pembelajaran Problem Posing tipe Presolution Posing, siswa membuat pertanyaan berdasarkan pernyataan (informasi) yang diberikan oleh guru.

Untuk mengimplementasikan pendekatan Problem Posing tipe Presolution Posing perlu adanya model pembelajaran yang mampu memberikan ruang bagi siswa atau guru. Pembelajaran ini akan mengarahkan siswa untuk bertindak berani, peduli, berbagi, dan 
menghargai orang lain serta aktif dalam pembelajaran Mekanika Teknik. Salah satu model pembelajaran yang mampu mengimplementasikan pendekatan Problem Posing tipe Presolution Posing adalah model pembelajaran kooperatif Think Pair Share (TPS).

Menurut Trianto (2009: 81), "Think Pair Share (TPS) adalah model pembelajaran yang dirancang untuk mempengaruhi pola interaksi siswa. Model pembelajaran kooperatif ini adalah model pembelajaran yang berpasangan di dalam kelompok." Dalam model pembelajaran ini guru hanya berperan sebagai fasilitator sehingga guru menyajikan satu materi dalam waktu pembahasan yang relatif singkat. Setelah itu giliran siswa untuk memikirkan secara mendalam tentang apa yang telah dijelaskan oleh guru. Langkah-langkah model pembelajaran Think Pair Share (TPS) menurut Arends (1997) adalah sebagai berikut:

a) Langkah 1: Berpikir (Thinking)

Guru mengajukan suatu pertanyaan atau masalah yang dikaitkan dengan pelajaran, dan meminta siswa menggunakan waktu beberapa menit untuk berpikir sendiri jawaban atau masalah.

b) Langkah 2: Berpasangan (Pairing)

Selanjutnya guru meminta siswa untuk berpasangan dan mendiskusikan apa yang telah mereka peroleh. Interaksi yang diharapkan dapat mendiskusikan hasil pekerjaan atau menyatukan gagasan.

c) Langkah 3: Berbagi (Sharing)
Pada langkah akhir, guru meminta pasangan-pasangan untuk berbagi dengan seluruh kelas.

Menurut Syaifuddin

Sagala (2005: 68) pendekatan pembelajaran merupakan jalan yang akan ditempuh oleh guru dan siswa dalam mencapai tujuan instruksional untuk suatu satuan instruksional tertentu.

Menurut Suyitno (dalam Mahabbah, 2014: 14) pada prinsipnya pendekatan pembelajaran Problem Posing adalah suatu pendekatan yang mewajibkan para peserta didik untuk mengajukan soal sendiri melalui belajar soal (berlatih soal) secara mandiri.

Pendekatan

Problem Posing

menekankan pada

pengajuan soal oleh peserta didik. Oleh karena itu, Problem Posing dapat menjadi salah satu alternatif untuk mengembangkan pola fikir peserta didik.

\section{METODE PENELITIAN}

Penelitian dilaksanakan di SMK

Negeri 4 Sukoharjo yang beralamat di Jl. Raya Baki No. 5 Jetis Baki Sukoharjo, Telp. (0271) 7891015, Kode Pos 57556.

Penelitian tindakan kelas ini merupakan kolaboratif partisipatoris, yaitu kerja sama antara peneliti dengan guru atau teman sejawat di lapangan. Peneliti terlibat langsung dalam perencanaan, pelaksanaan, observasi dan refleksi.

Waktu yang digunakan untuk penelitian dan penyusunan dimulai dari pengajuan judul pada bulan Januari 2018, seminar 
proposal pada tanggal 28 Februari 2018, observasi pra siklus pada tanggal 15 April 2018, siklus I dilaksanakan pada tanggal 22 April 2018, setelah itu siklus II dilaksanakan pada tanggal 29 April 2018.

\section{HASIL DAN PEMBAHASAN \\ 1) Data Hasil Belajar Pra Siklus}

Berdasarkan data yang diperoleh dari latihan soal saat kegiatan pra siklus, dari 30 siswa hanya 5 siswa yang mampu mencapai target ketuntasan belajar. Berikut ini tabel perbandingan hasil analitis data dan ketuntasan belajar pada tahap pra siklus. Tabel 1. Data Hasil Belajar Pra

Siklus

\begin{tabular}{lc}
\hline \multicolumn{1}{c}{ Hasil Tes Awal } & Nilai \\
\hline Nilai siswa terendah & 37,5 \\
\hline Nilai siswa tertinggi & 80 \\
\hline Rata-rata kelas & 55.16 \\
\hline Persentase Ketuntasan & $16,67 \%$ \\
\hline
\end{tabular}

Berikut ini adalah tabel perbandingan hasil data pra siklus dengan indikator kinerja penelitian untuk ranah kognitif, ranah psikomotor dan ranah afektif.

Tabel 2. Ketuntasan Belajar Siswa Pra Siklus untuk Ranah

Kognitif

\begin{tabular}{ccc}
$\begin{array}{c}\text { Jumlah } \\
\text { Siswa }\end{array}$ & Pencapaian & Ket. \\
\hline 5 & $16,67 \%$ & Tuntas \\
\hline
\end{tabular}

gambar 1.

\section{Persentase Ketuntasan}

Belajar Pra Siklus Ranah Kognitif

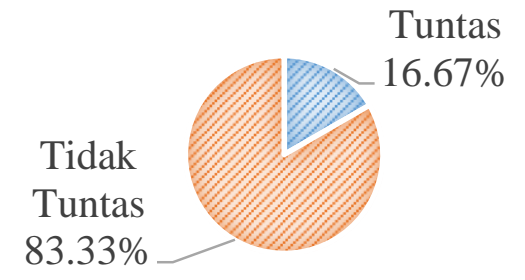

$\begin{array}{crr}\text { Gambar } & \text { 1. Diagram } & \text { Persentase } \\ 25 & 83,33 \% & \text { Tdk Tuntas }\end{array}$

Tabel 2. menujukkan bahwa untuk ranah kognitif mayoritas siswa yaitu berjumlah 25 orang belum mencapai kriteria ketuntasan minimal, untuk lebih jelasnya dapat dilihat pada

Ketuntasan Belajar Ranah Kognitif Pra Siklus

Tabel 3. Ketuntasan Belajar Siswa Pra Siklus untuk Ranah

Psikomotor

\begin{tabular}{ccl}
\hline $\begin{array}{c}\text { Jumlah } \\
\text { Siswa }\end{array}$ & Pencapaian & Keterangan \\
\hline 8 & $26,67 \%$ & Tuntas \\
\hline 22 & $73,33 \%$ & Tdk Tuntas \\
\hline
\end{tabular}

Tabel di atas menunjukkan hasil belajar ranah psikomotor siswa kelas $X$ DPIB A di SMK Negeri 4 Sukoharjo. Dari 30 siswa masih terdapat 22 siswa belum mencapai kriteria ketuntasan minimal, untuk lebih jelasnya dapat dilihat pada 
Gambar 2. Diagram Persentase

Ketuntasan Belajar Ranah

Psikomotor Pra Siklus

Tabel 4. Ketuntasan Belajar Siswa

Pra Siklus untuk Ranah

Afektif

gambar 2.
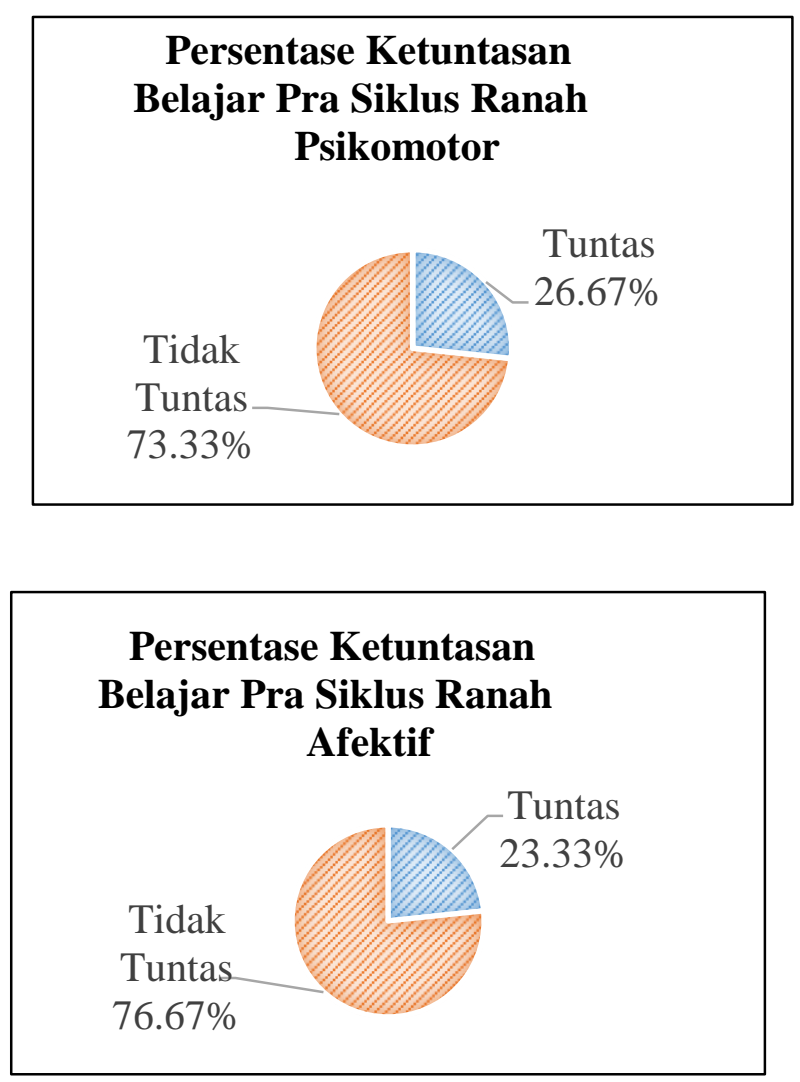

Gambar 3. Diagram Persentase Jumlah Pencapaian Keterangan

\begin{tabular}{cll} 
Siswa & & \\
\hline 7 & $23,33 \%$ & Tuntas \\
\hline 23 & $76,67 \%$ & Tdk Tuntas \\
\hline
\end{tabular}

Tabel di atas menunjukkan mayoritas siswa kelas X DPIB A di SMK Negeri 4 Sukoharjo yang berjumlah 23 siswa belum mencapai kriteria ketuntasan minimal, untuk lebih jelasnya dapat dilihat pada gambar 3 .

\author{
Ketuntasan Belajar \\ Ranah \\ Afektif Pra Siklus
}

Tabel 5. Pencapaian Ketuntasan

Tindakan Pra Siklus

\begin{tabular}{llll}
\hline $\begin{array}{c}\text { Aspek } \\
\text { Pra }\end{array}$ & Target & Indikator \\
\hline \multicolumn{3}{c}{ Nilai } & \multicolumn{1}{c}{ Siklus } \\
KOG & 76 & $70 \%$ & $16,67 \%$ \\
\hline PSI 76 & $70 \%$ & $26,67 \%$ \\
AFK & 76 & $70 \%$ & $23,33 \%$ \\
\hline
\end{tabular}

Dari tabel di atas dapat diketahui bahwa hasil belajar siswa pada pra siklus di kelas $\mathrm{X}$

DPIB A SMK Negeri 4

Sukoharjo belum memenuhi nilai ketuntasan minimum. Hasil pra siklus akan digunakan untuk masukan dalam menerapkan model pembelajaran kooperatif Think Pair Share (TPS) dengan pendekatan Problem Posing menggunakan Desain Pembelajaran ASSURE, dengan beberapa rencana tindakan sebagai berikut:

Tabel 6. Refleksi Pra Siklus

\begin{tabular}{|l|l|l|}
\hline No. & Refleksi Pra Siklus & Rencana Tindakan Siklus I \\
\hline 1. & $\begin{array}{l}\text { Pembelajaran } \\
\text { cenderung } \\
\text { terpusat }\end{array}$ & $\begin{array}{l}\text { Penggunaan model } \\
\text { pembelajaran kooperatif Think } \\
\text { Pair Share (TPS) dengan } \\
\text { pendekatan Problem Posing } \\
\text { menggunakan Desain } \\
\text { Pembelajaran ASSURE. }\end{array}$ \\
\hline 2. & $\begin{array}{l}\text { Tidak sedikit hasil } \\
\text { belajar siswa yang } \\
\text { belum memenuhi } \\
\text { target ketuntasan. }\end{array}$ & $\begin{array}{l}\text { Memperbaiki hasil belajar } \\
\text { siswa dengan aspek yang } \\
\text { diukur meliputi aspek kognitif, } \\
\text { aspek psikomotor dan aspek } \\
\text { afektif. }\end{array}$ \\
\hline
\end{tabular}

\section{2) Data Hasil Belajar Siklus I}

Tabel 7. Data Hasil Belajar Siklus I 


\begin{tabular}{lc}
\hline \multicolumn{1}{c}{ Hasil Tes Awal } & Nilai \\
\hline Nilai siswa terendah & 37,5 \\
\hline Nilai siswa tertinggi & 82,5 \\
\hline Rata-rata kelas & 61,68 \\
\hline Persentase Ketuntasan & $46,67 \%$ \\
\hline
\end{tabular}

Berikut ini adalah tabel perbandingan hasil data pra siklus dengan indikator kinerja penelitian untuk ranah kognitif, ranah psikomotor dan ranah afektif.

Tabel 8. Ketuntasan Belajar Siswa gambar 4.

\section{Persentase Ketuntasan \\ Belajar Siklus I Ranah Kognitif}

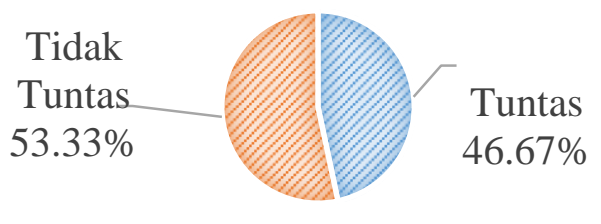

Gambar 4. Diagram Persentase Siklus I untuk Ranah

Kognitif

\begin{tabular}{ccl}
\hline $\begin{array}{c}\text { Jumlah } \\
\text { Siswa }\end{array}$ & Pencapaian & Keterangan \\
\hline 14 & $46,67 \%$ & Tuntas \\
\hline 16 & $53,33 \%$ & Tdk Tuntas \\
\hline
\end{tabular}

Tabel 8 menujukkan bahwa untuk ranah kognitif mayoritas siswa yaitu berjumlah 16 orang belum mencapai kriteria ketuntasan minimal, untuk lebih jelasnya dapat dilihat pada Ketuntasan Belajar Ranah Kognitif Siklus I
Tabel 9. Ketuntasan Belajar Siswa Siklus I untuk Ranah Psikomotor

\begin{tabular}{ccl}
\hline $\begin{array}{c}\text { Jumlah } \\
\text { Siswa }\end{array}$ & Pencapaian & Keterangan \\
\hline 14 & $46,67 \%$ & Tuntas \\
\hline 16 & $53,33 \%$ & Tdk Tuntas \\
\hline
\end{tabular}

Tabel di atas menunjukkan hasil belajar ranah psikomotor siswa kelas X DPIB A di SMK Negeri 4 Sukoharjo. Dari 30 siswa masih terdapat 16 siswa belum mencapai kriteria ketuntasan minimal, untuk lebih jelasnya dapat dilihat pada gambar 5.

\section{Persentase Ketuntasan \\ Belajar Siklus I Ranah Psikomotor}

Tidak

Tuntas $53.33 \%$ Tuntas 46.67\% Gambar 5.

Diagram Persentase Ketuntasan

Belajar Ranah

Psikomotor Siklus I

Tabel 10. Ketuntasan Belajar Siswa Siklus I untuk Ranah Afektif

\begin{tabular}{ccl}
\hline $\begin{array}{c}\text { Jumlah } \\
\text { Siswa }\end{array}$ & Pencapaian & Keterangan \\
\hline 13 & $43,33 \%$ & Tuntas \\
\hline 17 & $56,67 \%$ & Tdk Tuntas \\
\hline
\end{tabular}

Tabel di atas menunjukkan mayoritas siswa kelas X DPIB A di SMK Negeri 4 Sukoharjo yang berjumlah 17 siswa belum mencapai kriteria ketuntasan minimal, untuk lebih jelasnya 
dapat dilihat pada gambar 6 .

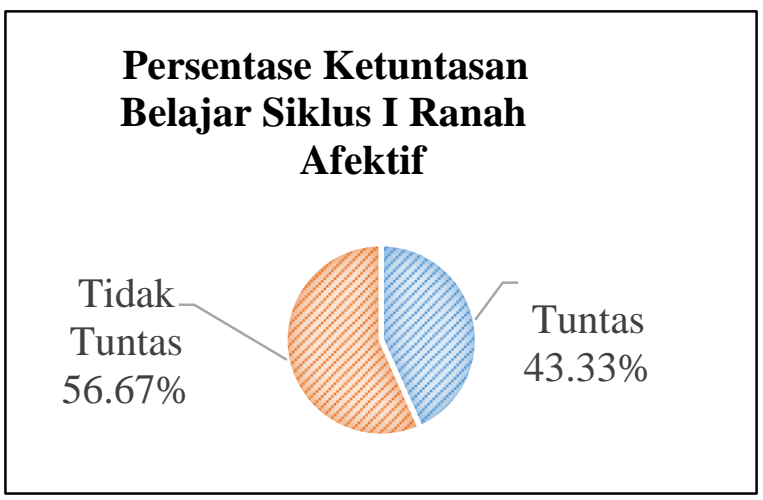

Gambar 6. Diagram Persentase

Ketuntasan Belajar

Ranah

Afektif Siklus I

Tabel 11. Pencapaian Ketuntasan Tindakan Siklus I

\begin{tabular}{lcll} 
Aspek & \multicolumn{2}{c}{ Target } & \multicolumn{2}{l}{ Siklus } & \\
& \multicolumn{2}{c}{ Indikator } & \\
& Nilai & I & \\
KOG & 76 & $70 \%$ & $46,67 \%$ \\
\hline PSI 76 & $70 \%$ & $46,67 \%$ & \\
\cline { 1 - 3 } AFK & 76 & $70 \%$ & $43,33 \%$ \\
\hline
\end{tabular}

Dari tabel di atas dapat diketahui bahwa hasil belajar siswa dari 3 ranah pada siklus I di kelas X DPIB A SMK Negeri 4 Sukoharjo sudah menunjukkan peningkatan namun belum sesuai dengan apa yang diharapkan sehingga perlu dilakukan siklus berikutnya yaitu siklus II. Hasil siklus I akan digunakan untuk masukan dalam tindakan siklus II, dengan beberapa rencana tindakan sebaga berikut:

Tabel 12. Refleksi Pra Siklus

\begin{tabular}{|c|c|c|} 
No. & Refleksi Siklus I & $\begin{array}{c}\text { Rencana Tindakan } \\
\text { Siklus II }\end{array}$ \\
\hline
\end{tabular}

\begin{tabular}{|l|l|lr|}
\hline 1. & $\begin{array}{l}\text { Siswa } \\
\text { berpasangan } \\
\text { orang dengan } \\
\text { teman } \\
\text { sebangkunya. }\end{array}$ & $\begin{array}{l}\text { Guru membuat } \\
\text { kelompok 6rang } \\
\text { berdasarkan tingkat } \\
\text { kecerdasan siswa yang } \\
\text { diperoleh dari hasil } \\
\text { siklus sebelumnya. }\end{array}$ \\
\hline 2. & $\begin{array}{l}\text { Target } \\
\text { pencapaian hasil } \\
\text { belajar siswa } \\
\text { belum tercapai. }\end{array}$ & $\begin{array}{l}\text { Memperbaiki hasil } \\
\text { belajar siswa dengan } \\
\text { beberapa perbaikan alur } \\
\text { pembelajaran dan soal } \\
\text { yang diberikan. }\end{array}$ \\
\hline
\end{tabular}

\section{3) Data Hasil Belajar Siklus II}

Tabel 13. Data Hasil Belajar Siklus II

\begin{tabular}{lc}
\multicolumn{1}{c}{ Hasil Tes Awal } & Nilai \\
\hline Nilai siswa terendah & 52,5 \\
\hline Nilai siswa tertinggi & 87,5 \\
\hline Rata-rata kelas & 77,13 \\
\hline Persentase Ketuntasan & $70 \%$ \\
\hline
\end{tabular}

Berikut ini adalah tabel perbandingan hasil data pra siklus dengan indikator kinerja penelitian untuk ranah kognitif, ranah psikomotor dan ranah afektif.

Tabel 14. Ketuntasan Belajar Siswa Siklus II untuk Ranah Kognitif 
gambar 7.

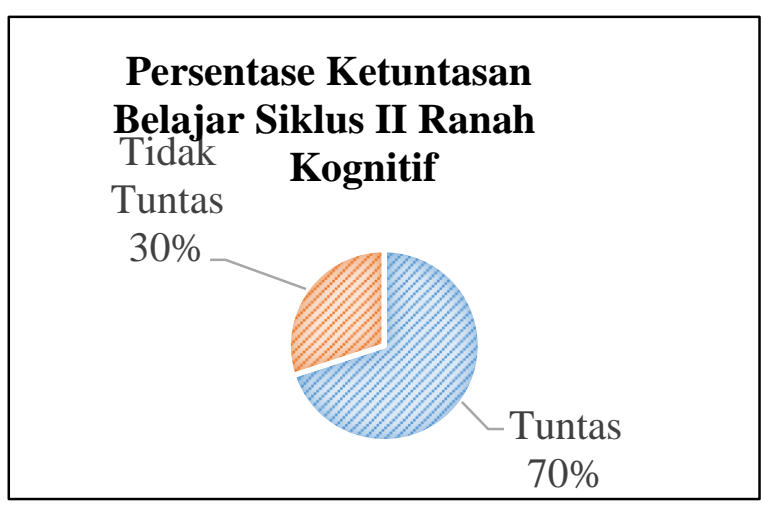

Gambar 7. Diagram Persentase

\begin{tabular}{ccl}
\hline $\begin{array}{c}\text { Jumlah } \\
\text { Siswa }\end{array}$ & Pencapaian & Keterangan \\
\hline 21 & $70 \%$ & Tuntas \\
\hline 9 & $30 \%$ & Tdk Tuntas \\
\hline
\end{tabular}

Tabel 14. menujukkan bahwa untuk ranah kognitif mayoritas siswa yaitu berjumlah 21 orang sudah mencapai kriteria ketuntasan minimal, untuk lebih jelasnya dapat dilihat pada Ketuntasan Belajar Ranah Kognitif Siklus II

Tabel 15. Ketuntasan Belajar Siswa Siklus II untuk Ranah Psikomotor

\begin{tabular}{|c|c|}
\hline $\begin{array}{l}\text { Jumlah Pencapaian } \\
\text { Siswa }\end{array}$ & Keterangan \\
\hline $73,33 \%$ & Tuntas \\
\hline $26,67 \%$ & Tdk Tuntas \\
\hline
\end{tabular}

Tabel di atas menunjukkan hasil belajar ranah psikomotor siswa kelas X DPIB A di SMK Negeri 4 Sukoharjo. Dari 30 siswa masih terdapat 16 siswa belum mencapai kriteria ketuntasan minimal, untuk lebih jelasnya dapat dilihat pada gambar 8 .
Gambar 8.Diagram Persentase Ketuntasan Belajar Ranah Psikomotor Siklus II

Tabel 16. Ketuntasan Belajar Siswa Siklus II untuk Ranah

\begin{tabular}{ccl}
$\begin{array}{c}\text { Afektif } \\
\text { Jumlah } \\
\text { Siswa }\end{array}$ & Pencapaian & Keterangan \\
\hline 21 & $70 \%$ & Tuntas \\
\hline 9 & $30 \%$ & Tdk Tuntas
\end{tabular}

Tabel di atas menunjukkan mayoritas siswa kelas X DPIB A di SMK Negeri 4 Sukoharjo yang berjumlah 21 siswa sudah mencapai kriteria ketuntasan minimal, sedangkan 9 siswa belum mencapai kriteria ketuntasan minimal, untuk lebih jelasnya dapat dilihat pada gambar 9.

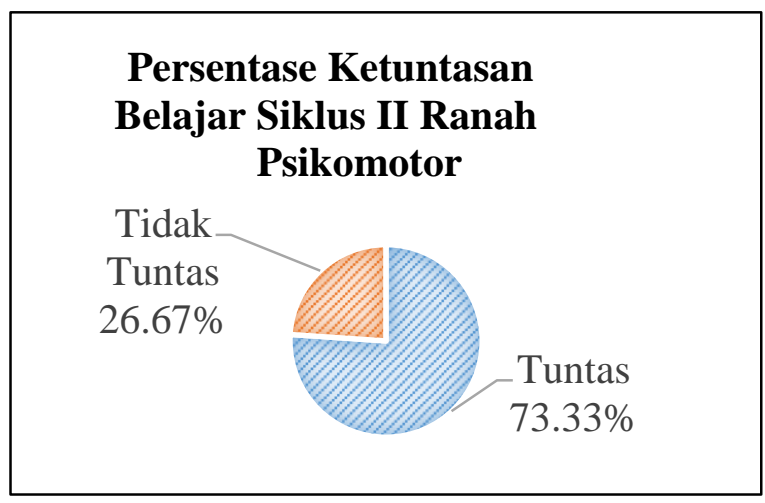




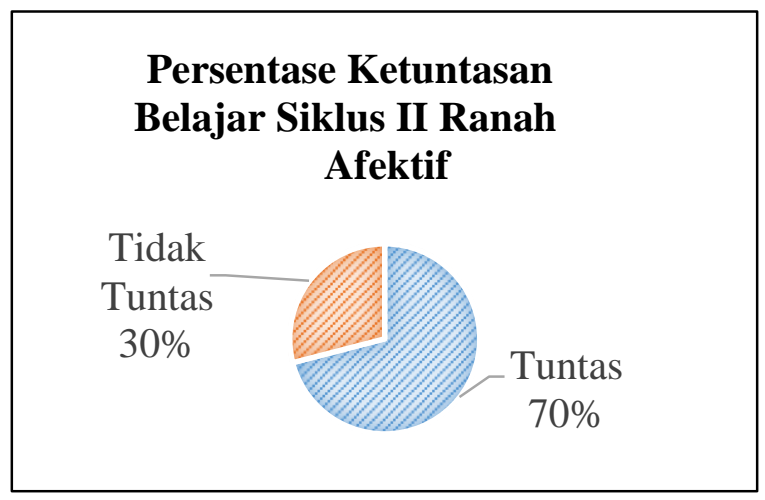

Gambar 9. Diagram Persentase

Ketuntasan

$$
\text { Ranah }
$$

Afektif Siklus II

Tabel 17. Pencapaian Ketuntasan Tindakan Siklus II

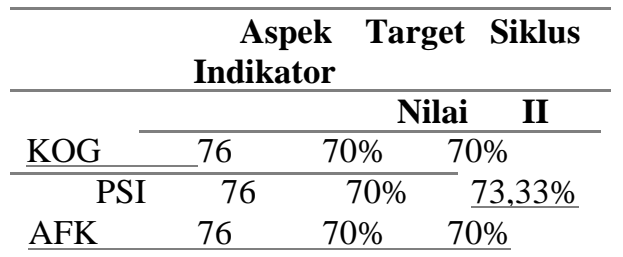

\section{4) Perbadingan Hasil Tindakan}

Hasil tes siswa untuk materi Gaya-gaya dalam (Momen, Geser dan Normal) menjadi data untuk ranah kognitif. Sedangkan ranah setiap siswa. Dari hasil diperoleh data hasil belajar siswa yang dapat dilihat sebagai berikut: Gambar 10. Diagram Pencapaian

Ketuntasan Hasil Belajar Siswa

\section{SIMPULAN}

Penelitian tindakan kelas

yang dilakukan pada mata pelajaran Mekanika

Teknik kelas afektif dan ranah psikomotor

\section{Pencapaian Ketuntasan Hasil Belajar Siswa}

E Pra Siklus $\quad$ Eiklus I $\quad$ Siklus II

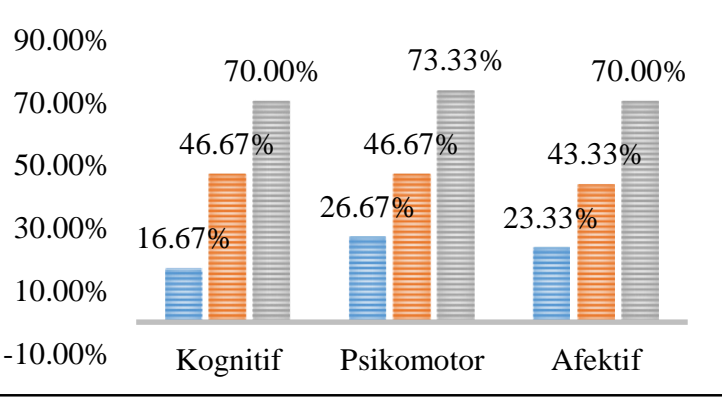

diperoleh dari observasi pada $X$ DPIB A SMK Negeri 4 Sukoharjo tahun ajaran 2017/2018 terkait penerapan Pembelajaran Kooperatif Model Think Pair Share (TPS) dengan Pendekatan Problem Posing menggunakan Desain

Pembelajaran ASSURE terdiri dari dua siklus yaitu siklus I dan siklus II. Kesimpulan dari analisis kedua siklus tersebut adalah:

1) Penerapan model pembelajaran kooperatif Think Pair Share (TPS) dengan pendekatan

Problem Posing menggunakan Desain Pembelajaran ASSURE dapat meningkatkan prestasi belajar siswa kelas X DPIB A SMKN 4 Sukoharjo. Hal tersebut dapat dilihat pada pencapaian ketuntasan hasil belajar siswa yang menunjukkan persentase ketuntasan ranah kognitif awalnya $16,67 \%$ menjadi 
46,67\% pada siklus I dan $70 \%$ pada siklus II; ranah psikomotor awalnya $26,67 \%$ menjadi $46,67 \%$ pada siklus I dan $73,33 \%$ pada siklus II; ranah afektif awalnya 23,33\% menjadi $43,33 \%$ pada siklus I dan $70 \%$ pada siklus II.

2) Terdapat beberapa kendala yang dihadapi dalam penerapan penerapan Pembelajaran Kooperatif Model Think Pair Share (TPS) dengan Pendekatan Problem Posing menggunakan Desain Pembelajaran ASSURE misalnya: lingkungan di sekitar sekolah yang kurang mendukung, perpindahan ruang pada setiap mata pelajaran, dan motivasi siswa dalam belajar masih perlu ditingkatkan.

\section{SARAN}

1. Bagi Siswa

a. Penerapan pembelajaran Kooperatif Model Think Pair Share (TPS) dengan Pendekatan Problem Posing menggunakan Desain Pembelajaran ASSURE hendaknya dapat dimanfaatkan siswa dengan baik sehingga prestasi belajar dapat semakin meningkat.

b. Adanya pembelajaran Kooperatif Model Think Pair Share (TPS) dengan Pendekatan Problem Posing menggunakan Desain Pembelajaran ASSURE diharapkan kedepannya siswa dapat menggunakannya sebagai saran belajar mandiri.

2. Bagi Guru

a. Dengan adanya pembelajaran Kooperatif Model Think Pair Share (TPS) dengan

Pendekatan

Problem Posing menggunakan Desain Pembelajaran ASSURE dapat memberikan masukan untuk menggunakan metode pembelajaran yang sesuai dengan materi yang diajarkan.

b. Adanya pembelajaran Kooperatif Model Think Pair Share (TPS) dengan Pendekatan Problem Posing menggunakan Desain Pembelajaran

ASSURE dapat memberikan alternatif metode untuk meningkatkan hasil belajar pada mata pelajaran Mekanika Teknik.

3. Bagi Sekolah

a. Adanya penelitian ini diharapkan dapat menjadi sumbangan pemikiran untuk meningkatkan prestasi SMKN 4

Sukoharjo di program keahlian bangunan khususnya pada mata pelajaran Mekanika

Teknik.

b. Diharapkan sekolah mampu menciptakan lingkungan sekolah yang nyaman untuk proses pembelajaran.

\section{DAFTAR PUSTAKA}

Arends, Richard I. 1997. Classroom Intructional Management. New York: The McGraw-Hill Company. 
Atmaha Rohmawati, Ulfia. 2015.

Peningkatan Kreativitas Berpikir Dan Hasil Belajar Melalui Penerapan Model Pembelajaran Kooperatif Think Pair Share dalam Mata Pelajaran Mekanika Teknik II Siswa Kelas X SMK Negeri 2 Surakarta. Surakarta: FKIP UNS.

Ramdhani Ciptaningtyas, Marina. 2015. Upaya Peningkatan Keaktifan Belajar dan Hasil Belajar Siswa Melalui Model Pembelajaran Matematika Kooperatif Tipe Think Pair Share (TPS) dengan Pendekatan Problem Posing dalam Pembelajaran Matematika Kelas VIII SMP Negeri 14 Surakarta Tahun Ajaran 2014/2015. Surakarta: FKIP UNS.

Sagala, Syaifudin. 2005. Konsep Dasar Makna Pembelajaran untuk Membantu Memecahkan Problematika Belajar dan Mengajar. Bandung: CV. Alfabeta

Trianto. 2009. Mendesain Model Pembelajaran InovatifProgresif. Jakarta. Kencana Prenada Media Group. 